\title{
Constipation in Elderly Population and Its Appropriate Management
}

\author{
Alvin Hartanto Kurniawan*, Ulfa Kholili**, Novira Widajanti*** \\ *Faculty of Medicine, Universitas Airlangga/Dr Soetomo General Hospital, Surabaya \\ ** Division of Gastroentero-hepatology, Department of Internal Medicine, Faculty of Medicine, \\ Universitas Airlangga/Dr Soetomo General Hospital, Surabaya \\ ${ }^{* * *}$ Division of Geriatric Medicine, Department of Internal Medicine, \\ Faculty of Medicine, Universitas Airlangga/Dr Soetomo General Hospital, Surabaya
}

\section{Corresponding author:}

Ulfa Kholili. Division of Gastroentero-hepatology, Department of Internal Medicine, Dr Soetomo General Hospital. Jl. Mayjen Prof. Dr. Moestopono.6-8 Surabaya Indonesia.Email: ulfakholili1975@gmail.com

\begin{abstract}
Constipation is a gastrointestinal disorder commonly found in the community, especially in the elderly with various comorbidities. This problem culminates with the increasing incidence along with aging, increasing therapeutic cost, and decreasing the quality of life in this population. Some of the underlying causes are the difference in the terminology of constipation, shallow understanding of its pathophysiology, and poor management. The pathophysiology, including slow transit constipation, dyssynergic defecation, and normal transit constipation, is the most critical foundation in managing constipation accordingly. Diagnostic approaches should be made by history taking, including complaints based on Rome III, lifestyle, contributing factors, past medical history, and medications. Physical examination is considered incomplete without rectal examination. Thorough history taking and comprehensive physical examination have more diagnostic value than additional physiological workup. Management of constipation consists of nonpharmacological and pharmacological approaches, such as conventional laxative or more recent agents with better efficacy. Therapeutical management should correspond to the underlying pathophysiology. Therefore it is important to be able to recognize constipation and make the right management approach in the elderly.
\end{abstract}

Keywords: constipation, elderly, therapy, management

\begin{abstract}
ABSTRAK
Konstipasi merupakan masalah gastrointestinal yang sering ditemukan di masyarakat, terutama pada orang tua dengan berbagai komorbid. Masalah ini makin berat dengan peningkatan insiden bersama dengan penuaan, peningkatan biaya terapeutik, dan penurunan kualitas hidup pada populasi ini. Beberapa penyebab yang mendasari adalah perbedaan terminology konstipasi, pemahaman yang rendah akan patofisiologi, dan manajemen yang buruk. Patofisiologi, seperti konstipasi transit lambat, disinergi defekasi, dan konstipasi transit normal, merupakan dasar paling penting dalam manajemen kosntipasi. Pendekatan diagnostik sebaiknya dibuat dengan anamnesis, termasuk keluhan menurut Rome III, gaya hidup, faktor penyerta, riwayat penyakit dahulu, dan obat-obatan. Pemeriksaan fisik dianggap tidak lengkap apabila belum dilakukan pemeriksaan rektum. Anamnesis yang lengkap dan pemeriksaan fisik secara komprehensif memiliki nilai diagnostik yang lebih dibandingkan pemeriksaan fisiologi tambahan. Manajemen konstipasi terdiri dari pendekatan non-farmakologi maupun farmakologi, seperti laksative konvensional ataupun obat-obatan terbaru dengan efikasi yang lebih baik. Manajemen terapuetik sebaiknya disesuaikan dengan patofisiologi yang mendasari. Karena itu, penting untuk dapat mengenali konstipasi dan membuat pendekatan manajemen yang benar pada orang tua.
\end{abstract}

Kata kunci: konstipasi, orang tua, terapi, manajemen 


\section{INTRODUCTION}

Constipation is a medical disorder that is often seen in the community, even in the elderly population, which accompanied by other risks and comorbidities that increased burdensome to patients. ${ }^{1} \mathrm{~A}$ various constipation rate in the community was found approximately $\sim 20-30 \%$ in the general patient population, but this number was found higher in the advanced age population, which is around 33.5\%. Particularly for the elderly with specific circumstances, the prevalence will be much higher. ${ }^{1,2}$ Then, a high constipation number had lead to a high expenditure burden from new constipated patient management, the annual cost for laxative agents, outpatient visits and inpatient administration of constipation, and investment of laxative drugs over-the-counter. ${ }^{3,4}$ Constipation yielded not only huge expenditure but also decreased quality of life in the elderly population based on the assessment of Short-Form 36 (SF-36) and Psychological General Well-Being (PGWB) scores. ${ }^{5}$

The fundamental issues of the high constipation prevalence and in its accompanying high costs are different terminology of constipation between patient and practitioner, incorrect pathophysiology awareness, and unsatisfied management results. The terminology from patients and medical personnel was often contrasting, which should be adjusted with Rome III criteria. The recognition of pathophysiology is often incorrect so that management results, such as better symptoms control, long-term efficacy, and the prevention of potential side effects, are also poor. ${ }^{6,7}$

Because constipation is a problem often encountered in society with its impact and underlying issues, which has been mentioned above, so in this review, it will be discussed the pathophysiology and management in diagnosis and therapy, both non-pharmacological and pharmacological, either conventional or modern, related to constipation in the elderly.

\section{EPIDEMIOLOGY AND BURDEN}

Beforehand, epidemiological data showed that the prevalence rate of constipation was quite varied around $\sim 20-30 \%$ depending on the research design, care setting, underlying conditions, and concepts that were used to explain what was called normal bowel function. ${ }^{8}$ Overall, the average prevalence of constipation in adults was $16 \%$, of which $33.5 \%$ accounted for the group aged between $60-110$ years. ${ }^{9}$ However, most studies showed that constipation would increase in consonance with age and sex. In
Asia, there was a high prevalence of constipation in China, South Korea, and Indonesia, about 15-23\% in women and $11 \%$ in men. ${ }^{10}$ In contrast, in North America, the prevalence of constipation was showed about $26 \%$ in women compared to $16 \%$ in men from the population aged over 65 years. However, the prevalence in the group over 80 years was found 34\% in women compared to $26 \%$ in men. Moreover, in the elderly, this number could escalate up to $50 \%$ in community-dwelling settings, $70 \%$ in nursing homes setting, or even $80 \%$ in the elderly population with long-term care. ${ }^{5,11}$

The arising problems in concordance with the increased prevalence of constipation in the elderly were cost issues and quality of life. The economic impact due to constipation was found quite significant in the United States, which showed by 2.5 million visits and 100000 inpatients annually. ${ }^{12}$ The average expenditure incurred for patients with constipation in the United States was between $\$ 250$ to $\$ 500$ per patient. At the same time, in European countries, the expenses for a new constipated patient were relatively $€ 310$, €951, and €441, in Netherland, Sweden, and Belgium, respectively. ${ }^{3,13,14}$ A considerable amount of expenses was also found in Romania regarding the annual cost for the laxative agents group was showed to be 15 million euros. ${ }^{15}$ Those numbers mentioned above showed that constipation bears a massive annual expenditure.

For the quality of life, it was found that patients with constipation were showed higher numbers of depression, anxiety, somatization, psychological distress, and other psychological status compared to younger subjects. ${ }^{16}$ Besides, with the SF-36 questionnaire and $\mathrm{PGWB}$, it was found that the scores of quality of life were significantly worse in elderly patients with constipation than patients with healthy bowel. Moreover, improved quality of life was noted following constipation treatment. Therefore, patients with constipation, especially in advanced age populations, which had various comorbidities, had a higher risk of social and quality of life disruptions so that it will result in their daily activities. ${ }^{17}$

\section{PATHOPHYSIOLOGY}

The pathogenesis of constipation was varied from genetic, socioeconomic status, low fiber diets, lack of fluid intake, lack of mobility, hormonal imbalance, side effects of drugs, et cetera. Nevertheless, in primary constipation in the elderly without warning alarm or secondary causes, two essential processes 
could result in constipation, such as slow colon transit and dyssynergic defecation. The following will further explain these two points that underlie primary constipation in the elderly. ${ }^{18}$

\section{Slow Transit Constipation}

Slow transit constipation (STC) is characterized by a prolonged transit time for stool through the colon. STC itself has been mentioned as one of the main factors of constipation in the elderly, as several studies had shown a decrease in colonic transit from the elderly population. ${ }^{19}$ STC in these elderly often occurred secondary to several conditions, as shown in Table $1 .{ }^{20}$ In physiological conditions, motor activity is irregular. It increases after eating and waking up and decreases during sleeping. In physiological conditions, the motor of the colon will be regulated by propulsive waves consisted of high (HAPC) and low amplitude propagated contraction (LAPC). However, patients with STC were showed significantly decreased in HAPC..$^{5,7}$ Then, patients with STC had also shown not only disturbances in intestinal coordination and motor function, including intrinsic and extrinsic innervation of smooth muscle but also loss of innervation of Interstitial Cells of Cajal. ${ }^{21}$ It is showed that in the elderly, there was a loss of intestinal neurons by $37 \%$ in older people combined with an increase in collagen and elastic fibers in the mesenteric ganglia compared to the younger population. ${ }^{22}$ Then, in the elderly, some factors aggravated STC consisted of increased collagen in the ascending colon that will disrupt coordination and motor intestine, and secondly, the existence numbers of the binding site of plasma endorphins. ${ }^{5}$

\section{Dyssynergic Defecation}

Dyssynergic Defecation (DD) is characterized by impaired normal coordination between the abdominal muscles and pelvic floor muscles in the process of straining during defecation. DD can initially begin as the altered evacuation of the rectum, which could be generated by a lack of propulsive strength and increased resistance of the stool release that will further increase the anal sphincter pressure, incomplete relaxation, and paradoxical contraction or dysynergy. ${ }^{9}$ The etiology of DD is currently unclear. There are several concepts proposed, including the maladaptive process of anal sphincter contraction, which may be resulted from pain or trauma, pelvic floor muscle dysfunction, or enteric nervous system disorders. ${ }^{12,23,24}$ Moreover, in elderly patients, it was also showed a decrease in the elasticity of the rectum wall with fibro-adipose degeneration, which yielded an increase in internal anal sphincter thickness. ${ }^{5}$ While in the elderly, there were also anatomical problems that generated several pelvic floor abnormalities (rectocele, sigmoidocele, or intussusception), thus explaining the divergences of constipation between women and men. ${ }^{12}$

These two things often co-occurred, but constipation could appear without those two factors, which is normal transit constipation. Therefore, it is necessary to consider irritable bowel syndrome, where symptoms usually improved after an evacuation, although IBS was more common in the younger population. ${ }^{5}$

\section{DIAGNOSTIC MANAGEMENT}

\section{History and Physical Examination}

Patients with constipation often presented with diverse symptoms, so practitioners should be scrutiny in history taking regarding complaints by patients. ${ }^{12}$ The definitions of constipation between patients and practitioners are often different, so it is necessary to explore deeply about patient complaints, which, if appropriate, will be more beneficial than functional examinations. ${ }^{6}$ Establishing patients with constipation by using Rome III criteria will help to diagnose (Table 2). ${ }^{2}$ Then, it is also important to explore other histories that could relate to constipation. These included particular drug consumption, the presence

Table 1. Common factors of constipation in elderly $5,8,11$

\begin{tabular}{|c|c|}
\hline Medication & $\begin{array}{l}\text { Analgesic (opioid, NSAID), tricyclic antidepressant, antihistamine, anticholinergic, anticonvulsant, } \\
\text { diuretic (furosemide and hydrochlorothiazide), iron Supplement, calcium supplement, antipsychotic, } \\
\text { antiparkinsonian antacids (calcium and aluminium), chemotherapy, resins antihypertensive, and } \\
\text { antidiarrheal }\end{array}$ \\
\hline Endocrine and metabolic disease & Diabetes mellitus, hypothyroidism, hyperparathyroidism, and chronic renal disease \\
\hline Electrolyte imbalance & Hypercalcemia, hypokalaemia, and hypermagnesemia \\
\hline Intestinal disorder & Cancer, anorectal abnormality, haemorrhoids, hernia, diverticulosis \\
\hline Myopathy and neurologic disorder & $\begin{array}{l}\text { Scleroderma, amyloidosis, dementia, stroke, Parkinson disease, spinal Cord Lesion, autonomic } \\
\text { neuropathy, multiple sclerosis }\end{array}$ \\
\hline Intestinal abnormality & Carcinoma, radiation fibrosis, surgical complication, adhesion \\
\hline Psychological & Depression, anxiety, eating disorder \\
\hline Other & General disability \\
\hline
\end{tabular}


of metabolic disorders such as diabetes mellitus, which is increasing in number, and other conditions that can affect the transit time of the colon (Table 1). ${ }^{11,25}$ Medication history is critical in the elderly, a polypharmacy population. Therefore, further consultation for drug replacement should be conducted to the expert, who provides the drug, if medication is suspected as the primary cause of constipation. ${ }^{26}$ Constipation itself could be accompanied by other symptoms in the urinary tract, such as urine retention, sexual dysfunction, and dyspareunia. ${ }^{12}$ Additionally, it is also necessary to ask about the amount of diet, fiber and water consumption, the history of laxatives use as well as physical activity, psychosocial problems, and functional capabilities. Alarm symptoms are a sudden change in bowel habit after 50 years, occurring in acute time, bloody stool, anemia, nausea, vomiting, inflammatory bowel disease, familial history of colon cancer, and significant pain. ${ }^{11,27}$

\section{Table 2. Rome III criteria for constipation diagnosis ${ }^{2}$}

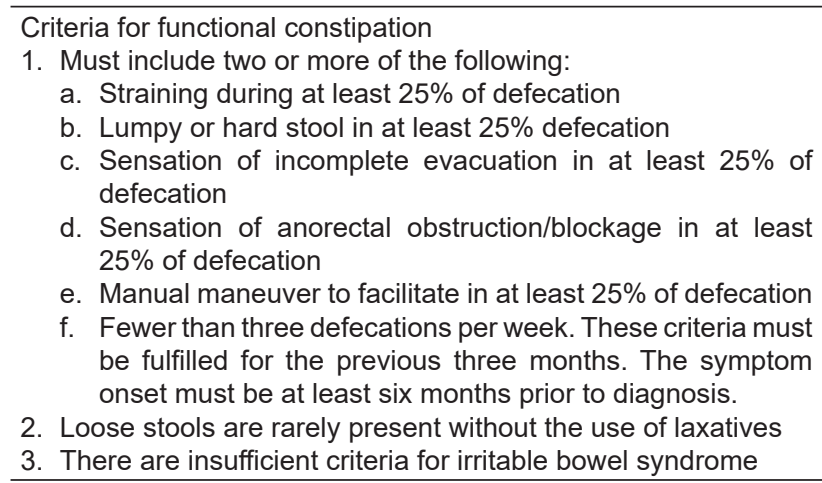

In the case of fecal impaction and incomplete evacuation, these problems were often diagnosed furthermore with fecal incontinence. Following the diagnosis, the patients were often given an anti-diarrhea drug, which will worsen the patient's condition with fecal impaction and secondary incontinence due to obstruction of the fecal material. Fecal impaction would also further cause bleeding in the rectum and stercoral ulcer, which potentially lead to fatal complications. ${ }^{12,28,29}$

A thorough physical examination would not be considered complete if a rectal examination had not been performed. Examination of the rectum will be useful in assessing not only the mass in the rectum but also in assessing the presence of strictures, fissures, and masses due to impaction from the fecal material as well as assessing the function of the pelvic floor function. ${ }^{30,31}$

\section{Additional Examination}

The initial additional examinations that should be performed are laboratory tests to rule out the diseases listed in Table 1. Additional examinations such as colonoscopy or barium enema could be used to rule out anatomical abnormalities in the intestine that might result in constipation. ${ }^{32}$ If these test results cannot explain the cause of constipation, then constipation should be suspected due to functional problems. Therefore, additional physiological examinations, such as anorectal manometry (ARM), balloon expulsion test (BET), and colonic transit study, should be considered. $^{27}$

\section{Anorectal manometry}

ARM will provide an overview of the pressure on the rectum and sphincter ani, as well as rectal sensations, anorectal reflexes, and rectal compliance. This examination will be beneficial to reveal patients with myopathy, neuropathy, and motor patterns disorders of the intestine. ${ }^{33}$ Under normal circumstances, pressure on the rectum will increase and followed by a decrease in pressure on the anal sphincter. Abnormality in this coordination would be the basis of the pathophysiology in the patient with dysynergic defecation. Rectal sensation in these patients would also be abnormal. These results indicate a higher threshold for sensation and drive for defecation. ${ }^{27}$

\section{Balloon expulsion test}

BET is a test that is often used in conjunction with ARM, in assessing the function of a pelvic floor. This examination is carried out in the left lateral position, by inserting a $4 \mathrm{~cm}$ long balloon made from silicon with $50 \mathrm{~mL}$ of warm water into the rectum. Under normal circumstances, this tool will be expelled in one minute. If the balloon has not come out for more than one minute, then there is a high suspicion of dysynergic defecation. ${ }^{34}$ However, one study reported that this examination only managed to show abnormalities from $23 \%$ to $67 \%$, which indicated that this examination needed to be accompanied by other methods. ${ }^{33}$

\section{Colonic transit study}

This examination can be performed with radiopaque markers, colonic scintigraphy, and wireless motility capsules. Examination with a radiopaque marker begins with the patient swallowing a capsule containing radiopaque material, which will be followed for 120 hours and re-evaluated on an X-ray. Normal transit time is established when the remaining number of markers is five or less or less than $20 \%$, while the prolonged transit time is diagnosed when the number of markers 
is six or more or more than $20 \%{ }^{27,35}$ This examination is considered cost-effective but has limitations due to radiation exposure for several days. Scintigraphy has the advantage of lower radiation exposure and shorter examination time (24-48 hours). ${ }^{36}$ Most recently, there was a wireless motility capsule that could be used to replace the radiopaque material. This examination provides an overview of not only the time of colonic transit but also on the stomach and small intestine. This examination was also free of radiation regardless of its high price and availability. ${ }^{37}$

\section{THERAPY MANAGEMENT}

\section{Non-pharmacologic}

Non-pharmacological therapy must be comprehensive, from lifestyle changes such as mild physical activity, daily recognition of urge to defecate, fluid and fiber intake, the probiotics use, and biofeedback therapy. Lifestyle changes and daily defecation routines could improve defecation patterns, which are considered as the first step of the therapy program. The best time to practice defecation is mainly in the morning after light physical exercise and breakfast, which would be assisted with a gastrocolic reflex. $^{5}$

Intake of fluid and fiber up to $30 \mathrm{~g} /$ day has been recommended. Nevertheless, in the elderly, it is necessary to consider any heart and kidney disease. Fiber intake, as a bulk laxative, had shown improvement in symptoms. However, fiber administration will not be useful in constipated patients due to STC or DD. ${ }^{38}$ Presently; the fiber could be obtained from a diet of vegetables, fruits, nuts, and seeds, or in ready-to-use forms, including psyllium seeds, methylcellulose, or calcium polycarbophil. Side effects of excessive fiber administration are stomach discomfort, flatulence, and bloating, which may be induced by intestinal microbiota fermentation. ${ }^{39,40}$ Fiber from vegetables and fruits that are recommended for constipation with mild symptoms was 20 to $35 \mathrm{~g}$ /day, which must be increased slowly from small doses. In contrast, for ready to use, psyllium is the best in improving symptoms. ${ }^{41}$

Probiotics are now widely used, based on alteration in normal gut flora that will occur in advanced age population. Probiotics had shown a slight increase in accelerating bowel transit, although they still required large and further randomized studies due to their inconsistent results. The advantage of probiotics administration over pharmacologic therapy was fewer side effects. ${ }^{42}$ Biofeedback therapy is the most effective therapy for dyssynergic defecation compared to other therapies because this method re-teaches adequate defecation efforts. This method was reported to be efficient without side effects by modulating neuromuscular pelvic floor muscles of patients. Patients were taught breathing techniques with the diaphragm to build impulse force from the stomach accompanied by synchronization to anal relaxation, which is evaluated using a probe inserted in the rectum. ${ }^{27,38}$

\section{Pharmacologic}

The first-line drug in patients with constipation in the elderly is laxative. ${ }^{43}$ There are three types of laxative: bulk, osmotic, and secretory. Bulk has been explained above, while the other two will be explained here. Although laxative administration should be gradual from bulk, followed by osmotic and then stimulant, it is important to note that laxative use should be individualized. ${ }^{40}$ An osmotic laxative is an agent that binds to the $\mathrm{H} 2 \mathrm{O}$ component in the intestine. This group consists of magnesium, lactulose, and polyethylene glycol (PEG). This class of drugs is the most given one to the elderly due to good results and quite safely in its long-term uses. ${ }^{5}$ The next group is stimulant laxative (such as bisacodyl and senna), which increases secretory activity, thereby increases water composition in the intestinal lumen and also increases enteric innervation so that motor activity is also increased. This drug is proven to be more effective than osmotic groups. Although it is beneficial, this drug should be kept as a reserve if laxative osmotic fails because studies of this drug in the elderly are still lacking. ${ }^{12}$ Beyond the price and the availability advantages of laxatives, these drugs have side effects such as abdominal discomfort, electrolyte imbalance, allergic reactions, and special attention to magnesiumbased laxatives. . $^{22,44}$

However, in cases where fecal impaction occurs, treatment with laxatives would not provide many benefits; in fact, bulk laxatives will only make things worse. In this case, manual disimpaction could be performed with lidocaine gel or enema. For maintenance, lifestyle changes accompanied by osmotic laxative administration such as lactulose or PEG could be applied. ${ }^{11}$ In the case of constipation induced by opioids, which is an agent that is often used in this population, a class of peripherally acting $\mu$-opioid receptor antagonists (PAMORAs) such as metilnaltrekson and naloxegol, could be employed if laxative does not work. PAMORAs act on $\mu$-receptor in gastrointestinal without penetrating 
the blood-brain barrier so that these groups do not reduce any analgesic effects. ${ }^{8,45}$

Nowadays, there are modern laxative preparations, such as the type 2 chloride channel activator (Lubiprostone), guanylate cyclase $\mathrm{C}$ receptor agonist (linaclotide, plecanatide), serotonin $5 \mathrm{HT}_{4}$ receptor agonists that work as prokinetics (prucalopride, norcisapride, velusetrag), enantiomer of 1.5 benzothiazepines (elobixibat). ${ }^{39,46}$ The mechanism of action and the side effects of these agents are summarized in Table 3.

Lubiprostone is a bicyclic fatty acid that performs on type 2 chloride channels in the apical membrane of intestinal epithelial cells. This agent yields chloride secretion so that fecal mass increases, intestinal wall stretching, and peristalsis activation without a direct effect on smooth muscle. ${ }^{47}$ Several studies had shown that this drug worked effectively in increasing bowel movements in the elderly population with side effects such as headache because of its similar structure to prostaglandins. ${ }^{4-50}$ Nevertheless, this report is quite rare compared to the younger population. ${ }^{50}$ Linaclotide, an agonist of cyclic cyclase $\mathrm{C}$ in apical intestinal cells, is the drug of choice for overcoming secondary problems related to constipation such as stool consistency, abdominal pain, and quality of life. ${ }^{51,52}$ In two studies, it was found that this agent was able to eliminate severe stomach complaints and improve the quality of life in the entire population. ${ }^{53,54}$ Even though its side effect was only diarrhea, but this drug was still not widely tested and needed to be considered in the elderly population. ${ }^{52}$ Prucalopride, an agent of the 5-hydroxytryptamine receptor group 4 , accelerates bowel movement by its effect on the mesenteric plexus. ${ }^{55,56}$ In contrast to drugs in this group such as tegaserod and mosapride, prucalopride has a low affinity for human Ether a-go-go Related Gene (hERG) proteins, which are known to cause undesirable cardiovascular effects. ${ }^{57}$ Furthermore, two studies showed that prucalopride was beneficial in the case of constipation in the elderly population, particularly those who lived in nursing homes. The most common adverse effects are headaches and gastrointestinal problems without any report of prolonged QT like other drugs in this group. ${ }^{58,59}$

Elobixibat is an inhibitor of ileal bile acid transporters so that it could increase bowel movement with all dosages, $5 \mathrm{mg}, 10 \mathrm{mg}$, and $15 \mathrm{mg}$. The study also found that bowel movement will increase along with dosage elevation, but this agent has side effects consisted of diarrhea and abdominal pain. ${ }^{60,61}$ Colchicine, an anti-inflammation drug, could be used as its side effects of diarrhea at high dosage. This drug has been proven to improve in STC. However, this agent has a narrow therapeutic index and has also been associated with serious adverse effects. ${ }^{62,63}$

These more modern medicines have proven to be more effective than conventional laxatives or placebo in reducing complaints and improving bowel movement and quality of life in chronic constipation. ${ }^{64,65}$ However, these drugs still need further studies related to its use in the elderly in terms of its effectiveness and safety because there are only a few studies in the elderly population. Additionally, these agents are quite expensive compared to conventional laxatives.

\section{Surgery}

Surgery performed on patients with constipation is the last option when all therapies fail to improve symptoms. Subtotal colectomy with ileorectal anastomosis is the procedure most commonly applied in cases of refractory slow transit constipation while noting the absence of DD. Side effects that often reported are diarrhea, incontinence, and obstruction..$^{27,66}$ However, it should be remembered that surgery would not improve severe complaints such as abdominal pain as well as considering the risk in older people with various comorbidities. ${ }^{67}$

\section{CONCLUSION}

Constipation is a gastroenterology disorder that is still often seen widely even in the elderly, a population with various accompanying comorbidities.

Table 3. Class, mechanism of action, and side effects of new constipation drugs ${ }^{5}$

\begin{tabular}{ll}
\hline Drug Class & $\begin{array}{l}\text { The mechanism to activate peristaltic and accelerate intestinal Side effect } \\
\text { transit }\end{array}$ \\
\hline Type 2 chloride channel Activator & $\begin{array}{l}\text { Chloride secretion in the intestinal lumen is followed by passive diffusion Nausea and Headache } \\
\text { of water and salt, thereby increasing fecal content and distension of the } \\
\text { intestinal wall. } \\
\text { Increases intracellular and extracellular cGMP levels; increases the levels Diarrhea according to } \\
\text { of chloride, bicarbonate, and water secretions into the lumen. } \\
\text { Expling neurons in the mesenteric plexus and acetylcholine release }\end{array}$ \\
$\begin{array}{ll}\text { 1,5-Benzothiazepines Enantiomer } \\
\text { Binding and inhibiting ileal bile acid transporters resulting in a build-up of Abdominal pain, } \\
\text { Diarrhoea }\end{array}$ \\
\hline
\end{tabular}


Constipation has also been known to provoke large expenditures and decreased quality of life in the elderly population. A better understanding of constipation pathophysiology in this population is vital in the management of diagnosis and therapy. A thorough history taking and physical examination in diagnosis will be constructive in determining the appropriate therapeutic approach. Currently available pharmacological options are laxatives and modern medicines, which are better for managing constipation. However, more research is needed regarding the safety and effectiveness of these modern drugs with larger multicenter randomized studies.

\section{CONFLICT OF INTEREST}

The authors stated there is no conflict of interest

\section{ACKNOWLEDGMENT}

We would like to thank the Dean of the Faculty of Medicine, Airlangga University, and the Director of Dr. Soetomo General Hospital.

\section{REFERENCES}

1. Gandell D, Straus SE, Bundookwala M, Tsui V, Alibhai SMH. Treatment of constipation in older people. CMAJ 2013;185:663-70.

2. Munch L, Tvistholm N, Trosborg I, Konradsen H. Living with constipation-older people's experiences and strategies with constipation before and during hospitalization. Int J Qual Stud Health Well-being 2016;11:30732.

3. Chevalier P, Lamotte M, Joseph A, Dubois D, Boeckxstaens G. In-hospital costs associated with chronic constipation in Belgium: A retrospective database study. Neurogastroenterol Motil 2014;26:368-76.

4. Rao SSC. Constipation: Evaluation and Treatment of Colonic and Anorectal Motility Disorders. Gastrointest Endosc Clin N Am 2009;36:687-711.

5. De Giorgio R, Ruggeri E, Stanghellini V, Eusebi LH, Bazzoli F, Chiarioni G. Chronic constipation in the elderly: A primer for the gastroenterologist. BMC Gastroenterol 2015;15:1-13.

6. Storr M. Chronic constipation: Current management and challenges. Can J Gastroenterol. 2011;25(SUPPL.B):5B-6B.

7. Cook IJ, Talley NJ, Benninga MA, Rao SS, Scott SM. Chronic constipation: Overview and challenges. Neurogastroenterol Motil. 2009;21:1-8.

8. Chokhavatia S, John ES, Bridgeman MB, Dixit D. Constipation in Elderly Patients with Noncancer Pain: Focus on OpioidInduced Constipation. Drugs and Aging 2016;33:557-74.

9. Bharucha AE, Pemberton JH, Locke GR. American gastroenterological association technical review on constipation. Gastroenterology 2013;144:218-38.

10. Gwee KA, Bergmans P, Kim JY, Coudsy B, Sim A, Chen M, et al. Assessment of the Asian neurogastroenterology and motility association chronic constipation criteria: An Asian multicenter cross-sectional study. J Neurogastroenterol Motil 2017;23:262-72.
11. Schuster BG, Kosar L, Kamrul R. Constipation in older adults: Stepwise approach to keep things moving. Can Fam Physician 2015;61:152-8.

12. Roque MV, Bouras EP. Epidemiology and management of chronic constipation in elderly patients. Clin Interv Aging 2015;10:919-30.

13. Wirta SB, Hodgkins P, Joseph A. Economic burden associated with chronic constipation in Sweden: A retrospective cohort study. Clin Outcomes Res 2014;6:369-79.

14. Dik VK, Siersema PD, Joseph A, Hodgkins P, Smeets HM, Van Oijen MGH. Constipation-related direct medical costs in 16887 patients newly diagnosed with chronic constipation. Eur J Gastroenterol Hepatol 2014;26:1260-6.

15. Albu A, Farcas A, David L, Dumitrascu DL. The economic burden of constipation therapy. Med Pharm Reports 2019;92:261-4.

16. Rao SSC, Seaton K, Miller MJ, Schulze K, Brown CK, Paulson J, et al. Psychological profiles and quality of life differ between patients with dyssynergia and those with slow transit constipation. J Psychosom Res 2007;63:441-9.

17. Tvistholm N, Munch L, Danielsen AK. Constipation is casting a shadow over everyday life - a systematic review on older people's experience of living with constipation. J Clin Nurs 2017;26:902-14.

18. Krogh K, Chiarioni G, Whitehead W. Management of chronic constipation in adults. United Eur Gastroenterol J 2017;5:465-72.

19. Wiskur B, Greenwood-Van Meerveld B. The aging colon: The role of enteric neurodegeneration in constipation. Curr Gastroenterol Rep 2010;12:507-12.

20. Nullens S, Nelsen T, Camilleri M, Burton D, Eckert D, Iturrino $\mathrm{J}$, et al. Regional colon transit in patients with dys-synergic defaecation or slow transit in patients with constipation. Gut 2012;61:1332-9.

21. Bassotti G, Villanacci V. Can "functional" constipation be considered as a form of enteric neuro-gliopathy? Glia 2011;59:345-50.

22. Bouras EP, Tangalos EG. Chronic Constipation in the Elderly. Gastroenterol Clin North Am 2009;38:463-80.

23. Whitehead WE, Di Lorenzo C, Leroi AM, Porrett T, Rao SS. Conservative and behavioural management of constipation. Neurogastroenterol Motil 2009;21:55-61.

24. Tack J, Müller-Lissner S, Stanghellini V, Boeckxstaens G, Kamm MA, Simren M, et al. Diagnosis and treatment of chronic constipation - a European perspective. Neurogastroenterol Motil 2011;23:697-710.

25. Kurniawan AH, Suwandi BH, Kholili U. Diabetic Gastroenteropathy: A Complication of Diabetes Mellitus. Acta Med Indones 2019;51:263-71.

26. Fragakis A, Zhou J, Mannan H, Ho V. Association between drug usage and constipation in the elderly population of greater Western Sydney Australia. Int J Environ Res Public Health 2018;15:226.

27. Rao SSC, Go JT. Update on the management of constipation in the elderly: new treatment options. Clin Interv Aging 2010;5:163-71.

28. Rey E, Barcelo M, Cebrián MJJ, Alvarez-Sanchez A, DiazRubio M, Rocha AL. A nation-wide study of prevalence and risk factors for fecal impaction in nursing homes. PLoS One 2014;9:e105281.

29. Lazarescu A, Turnbull GK, Vanner S. Investigating and treating fecal incontinence: When and how. Can J Gastroenterol 2009;23:301-8. 
30. Alame AM, Bahna H. Evaluation of constipation. Clin Colon Rectal Surg 2012;25:5-11.

31. Talley NJ. How to do and interpret a rectal examination in gastroenterology. Am J Gastroenterol 2008;103:820-2.

32. Beck DE. Evaluation and Management of Constipation. Ochsner J 2008;8:25-31.

33. Rao SSC, Meduri K. What is necessary to diagnose constipation? Best Pract Res Clin Gastroenterol 2011;25:127-40.

34. Rao SSC, Patcharatrakul T. Diagnosis and treatment of dyssynergic defecation. J Neurogastroenterol Motil 2016;22:423-35.

35. Kim ER, Rhee PL. How to interpret a functional or motility test - colon transit study. J Neurogastroenterol Motil 2012;18:94-9.

36. Camilleri M. Scintigraphic biomarkers for colonic dysmotility. Clin Pharmacol Ther 2010;87:748-53.

37. Saad RJ, Hasler WL. A Technical Review and Clinical Assessment of the Wireless Motility Capsule. Gastroenterol Hepatol 2011;7:795-804.

38. Foorotan M, Bagheri N, Darvishi M. Chronic Constipation. Medicine (Baltimore). 2018;97:e10631.

39. Ford AC, Moayyedi P, Lacy BE, Lembo AJ, Saito YA, Schiller LR, et al. American college of gastroenterology monograph on the management of irritable bowel syndrome and chronic idiopathic constipation. Am J Gastroenterol 2014;109:S2-26.

40. Fleming V, Wade WE. A review of laxative therapies for treatment of chronic constipation in older adults. Am J Geriatr Pharmacother 2010;8:514-50.

41. Portalatin M, Winstead N. Medical management of constipation. Clin Colon Rectal Surg 2012;25:12-9.

42. Miller LE, Ouwehand AC. Probiotic supplementation decreases intestinal transit time: Meta-analysis of randomized controlled trials. World J Gastroenterol 2013;19:4718-25.

43. Basilisco G, Coletta M. Chronic constipation: A critical review. Dig Liver Dis 2013;45:886-93.

44. Nyberg C, Hendel J, Nielsen OH. The safety of osmotically acting cathartics in colonic cleansing. Nat Rev Gastroenterol Hepatol 2010;7:557-64.

45. Nelson AD, Camilleri M. Chronic opioid induced constipation in patients with nonmalignant pain: Challenges and opportunities. Therap Adv Gastroenterol 2015;8:206-20.

46. Crowell MD, Harris LA, Lunsford TN, DiBaise JK. Emerging drugs for chronic constipation. Expert Opin Emerg Drugs 2009; 14:493-504.

47. Crowell MD, Harris LA, DiBaise JK, Olden KW. Activation of type-2 chloride channels: A novel therapeutic target for the treatment of chronic constipation. Curr Opin Investig Drugs 2007;8:66-70.

48. Johanson JF, Morton D, Geenen J, Ueno R. Multicenter, 4-week, double-blind, randomized, placebo-controlled trial of lubiprostone, a locally-acting type- 2 chloride channel activator, in patients with chronic constipation. Am J Gastroenterol 2008;103:170-7.

49. Barish CF, Drossman D, Johanson JF, Ueno R. Efficacy and safety of lubiprostone in patients with chronic constipation. Dig Dis Sci 2010;55:1090-7.

50. Gras-Miralles B, Cremonini F. A critical appraisal of lubiprostone in the treatment of chronic constipation in the elderly. Clin Interv Aging 2013;8:191-200.

51. Roque MV, Camilleri M. Linaclotide, a synthetic guanylate cyclase $\mathrm{C}$ agonist, for the treatment of functional gastrointestinal disorders associated with constipation. Expert Rev Gastroenterol Hepatol 2011;5:301-10.
52. Rey E, Mearin F, Alcedo J, Ciriza C, Delgado-Aros S, Freitas $\mathrm{T}$, et al. Optimizing the Use of Linaclotide in Patients with Constipation-Predominant Irritable Bowel Syndrome: An Expert Consensus Report. Adv Ther 2017;34:587-98.

53. Rao SSC, Quigley EMM, Shiff SJ, Lavins BJ, Kurtz CB, MacDougall JE, et al. Effect of Linaclotide on Severe Abdominal Symptoms in Patients With Irritable Bowel Syndrome With Constipation. Clin Gastroenterol Hepatol 2014;12:616-23.

54. Chey WD, Lembo AJ, Lavins BJ, Shiff SJ, Kurtz CB, Currie MG, et al. Linaclotide for irritable bowel syndrome with constipation: A 26-week, randomized, double-blind, placebo-controlled trial to evaluate efficacy and safety. Am J Gastroenterol 2012;107:1702-12.

55. De Giorgio R, Barbara G, Furness JB, Tonini M. Novel therapeutic targets for enteric nervous system disorders. Trends Pharmacol Sci 2007;28:473-81.

56. Quigley EMM. Prucalopride: Safety, efficacy and potential applications. Therap Adv Gastroenterol 2012;5:23-30.

57. Omer A, Quigley EMM. An update on prucalopride in the treatment of chronic constipation. Therap Adv Gastroenterol 2017; $10: 877-87$

58. Camilleri M, Beyens G, Kerstens R, Robinson P, Vandeplassche L. Safety assessment of prucalopride in elderly patients with constipation: A double-blind, placebo-controlled study. Neurogastroenterol Motil 2009;21:1256-e117.

59. Müller-Lissner S, Rykx A, Kerstens R, Vandeplassche L. A double-blind, placebo-controlled study of prucalopride in elderly patients with chronic constipation. Neurogastroenterol Motil 2010;22:991-8.

60. Chey WD, Camilleri M, Chang L, Rikner L, Graffner H. A randomized placebo-controlled phase IIb trial of A3309, a bile acid transporter inhibitor, for chronic idiopathic constipation. Am J Gastroenterol 2011;106:1803-12.

61. Chedid V, Vijayvargiya P, Camilleri M. Elobixibat for the treatment of constipation. Expert Rev Gastroenterol Hepatol 2018;12:951-60.

62. Taghavi SA, Shabani S, Mehramiri A, Eshraghian A, Kazemi SMH, Moeini M, et al. Colchicine is effective for short-term treatment of slow transit constipation: A double-blind placebocontrolled clinical trial. Int J Colorectal Dis 2010;25:389-94.

63. Bassotti G, Blandizzi C. Understanding and treating refractory constipation. World J Gastrointest Pharmacol Ther 2014;5:77-85.

64. Lembo AJ, Kurtz CB, MacDougall JE, Lavins BJ, Currie MG, Fitch DA, et al. Efficacy of Linaclotide for Patients With Chronic Constipation. Gastroenterology 2010;138:886-95.e1.

65. Tack J, Stanghellini V, Dubois D, Joseph A, Vandeplassche L, Kerstens R. Effect of prucalopride on symptoms of chronic constipation. Neurogastroenterol Motil 2014;26:21-7.

66. Liu LWC. Chronic constipation: Current treatment options. Can J Gastroenterol 2011;25:22B-28B.

67. Pfeifer J. Surgical options to treat constipation: A brief overview. Rozhl Chir 2015;94:349-61. 